\title{
The Image of Schools and Teachers in Recent American Fiction for Children and Pre-Adolescents
}

\author{
Diane E Bushner
}

$\mathrm{T}$ To view schools and teachers in recent American fiction for children and pre-adolescents, I shall compare the pedagogical context for schools and teachers today with the portrayal of schools and teachers in recent children's literature. This purpose of my paper is reflected in a recent quote from Regendering the School Story:

Yet for academics who care about teaching and learning - cultural critics, say, who examine not just culture, and not just its traces in texts, but also our own teaching as reproducing and subverting culture - school stories comprise an ideal locus for study.

(Clark, 1996, p.10)

Thus, the school story with teachers as a dominant character is the locus of my article. Parameters of pedagogy and practice will define this paper. As a teacher educator, my interests involve not only children becoming readers, but also that my pre-service teachers see models of their future profession in the genre of school stories that children read along with models in actual classrooms.

At the beginning of the twenty-first century, accountability and high standards are the driving force for schools and teachers in both Australia and the United States. In most states in both countries, subject area standards (White 2000) or frameworks (Commonwealth of Massachusetts 2000) are tools to reach high standards in schools. In the process of reaching high standards or educational reform, the teacher is key. Shulman (1999, p.xii) reiterated and extended this statement in the preface of Teaching as the Learning Profession: Handbook of Policy and Practice. In addition to carrying on society's cultural, intellectual and aesthetic achievements, Shulman acknowledges that teachers need to have a deep and flexible understanding for the subject(s) they are teaching. This deep understanding of the subject(s) taught is necessary to ensure that students will understand the subject(s) and will be excited by them.

If teachers are the key to the learning process, then I shall expect literature for American children and preadolescents who have a teacher as a major protagonist to view the image of teacher as critical to the learning process and that teachers will display a strong knowledge of the subject(s) they teach. Thus, ideally when children and pre-service teachers read books with teachers as major characters, they should find strong images of teachers. The school stories considered in this paper will be primarily realistic fiction with some animal fantasy for young readers. Both genres focus on teachers in realistic settings. Usually American school stories are not critiqued favorably within the field of children's literature, but they are popular with their intended audience of young readers. Often school stories do not leave the boundaries of the country where the book was published initially. Thus, some of the titles that follow may not be familiar to an international audience.

The sub-genre of school stories began in the nineteenth century with boarding school stories from England. Today, Tom Brown's Schooldays (1856) stands as a reminder of the early vintage of school stories. In the twentieth century, these early boarding school stories from England soon gave rise to school stories that depicted the changing educational experiences of children in the United States. The elite boarding school experience was exchanged for universal education, available to all, and funded by the government. There is a sizeable number of schools where parents pay for their children to attend school, but these schools do not dominate the current school stories. Again, the appeal of this generation of school stories continues to focus on the child protagonist and frequently school stories are mixed with humour, often caused by the child protagonist.

Durrington (1994) published an article titled: 'Novel Teachers: The Image of Teachers in Australian Children's Literature'. She concluded that all sorts of teachers were pictured in Australian children's literature. However, she found that the more positive images of teachers occurred in more recent works, particularly those depicting primary schools. Moore (1995) presented a research report on American 'Teachers, Teaching, and Classrooms in Children's Literature: How Authors and Illustrators Portray Schooling'. Moore concluded that if books have an effect on children, they would likely view teaching as a non-demanding job requiring little work or preparation. She did not find fictional teachers beyond the primary grades as very supportive of the learners.

Trousdale (1994) examined fictional picture books for 
young children published between 1960 and 1990 . These books presented a wide spectrum of images of teachers ranging from sensitive or nurturing to authoritarian or mean. Mainly the population of teachers was white, Anglo-Saxon, and female. Burnaford (1994) focused on teacher images in literature for older children or fiction read in upper primary or middle schools. These works were published in the 1970 s and 1980s. The images of these teachers were varied and ranged from stereotypical to very unique teachers. In short, teachers conformed or they risked dismissal from the teaching profession. Just as with the study of picture books, the race and gender of the teachers was mostly white and female.

This paper will focus on recently published school stories in an effort to view the image of the contemporary teacher. The selected stories have been published in the 1990 s or later. In this way, there will be no overlap with titles in the Trousdale or Burnaford articles. Also, these recent texts will further test the Durrington hypothesis that proposes that contemporary books have more favorable images of teachers.

The major focus of my selected literature will be fiction for children and pre-adolescents that include contemporary teachers as a significant character in each title. I used the subject index in the Horn Book Guide to locate fictional titles with teachers as a major protagonist. Clearly, selected books show the teacher engaging in the role of the teacher. I am looking to see if there is evidence of the pedagogy employed by these teachers and whether there is evidence of subject matter knowledge possessed by these teachers. American fiction for children, with significant teacher characters in both picture books and novels, will be discussed according to the grade range taught by the teacher character.

Stories about Teachers in Kindergarten or Teaching Five Year Olds

The study by Moore (1995) and the article by Trousdale (1994) both spoke of the nameless teacher who taught many young children. In all the books about kindergarten teachers in my paper, the teachers have names. Hence, it appears that the problem of the nameless teacher, cited in books with earlier publishing dates, is over. All the authors are treating teachers with respect and give each of them a proper name. The teachers also have a range of titles ranging from the traditional Miss to Ms, Mrs, and even Mr. The children in these books love their teachers: Mrs Greenstein and Ms Boscobel, (Hurwitz 1998); Mrs Bee, (Martin 1992); Mr Slinger, (Henkes 1996); Miss Bindergarten, (Slate 1996, 1998, 2000); Miss Cribbage (Wells 2000a); and Mrs Jenkins (Wells 2000b, 200la, and $200 \mathrm{lb}$ ). At one point Lilly becomes angry with $\mathrm{Mr}$ Slinger (Henkes 1996) and draws an uncomplimentary picture of him, but that problem was worked out in the course of the story by Lilly's parents. This is the only story in which a kindergarten character expresses anger toward a teacher. Whether the story is told in a realistic genre or in animal fantasy, the kindergarten children love their teachers. In fact, teachers who teach five year olds are among the most positively presented teachers in all of children's literature.

The clothes or appearance of the kindergarten teachers are a focus of the story of the animal fantasy texts. First, the text in the animal fantasy portrays the look of a traditional classroom experience. It is only when readers look at the-picture that they become aware that the characters are animals. The text is often minimal and presents the teachers in a realistic mode. Mouse characters abound in Lilly's Purple Plastic Purse (Henkes 1996). Likewise, Mr Slinger, the teacher, is a mouse character. $\mathrm{Mr}$ Slinger wears artistic shirts, glasses on a chain around his neck, and a different coloured tie for each day of the week. Miss Bindergarten, a canine, is the kindergarten teacher who appears in a series of three picture books (Slate 1996, 1998 and 2000). Miss Bindergarten wears dresses with pinafore aprons. Miss Bindergarten's clothes are the least flashy of all the kindergarten teachers sampled. Yet, she appears very presentable. The reader learns that Miss Bindergarten cares about her appearance as she looks in a mirror to check her makeup and to refresh her lipstick before the children arrive for the first day of school after she finishes setting up her classroom.

In Emily's First 100 Days of School (Wells 2000a), the reader meets Miss Cribbage who is a well-dressed cat, and she often wears clothes displaying the motif of whatever she is teaching. Wells recently reissued the familiar Timothy Goes to School by adding new illustrations (2001b). The reader meets Mrs Jenkins, the 
teacher, another cat. Mrs Jenkins appears lavishly dressed, wearing red heels and a plaid dress with a yellow jacket. Mrs Jenkins wears pinch-nose spectacles. Mrs Jenkins appears as the teacher again in Letters and Sounds (Wells 2001a) and How Many? How Much? (Wells 2001b). Mrs Jenkins is still wearing her red heels, plaid dress, and pinch-nose glasses but now her yellow jacket is adorned with either letters or numbers. The animal fantasy books focus on the description of the clothes worn by the teacher and whether teachers wear glasses. This realistic description of the teachers' clothes is one of the things that help make these books so realistic. However, in reality, many teachers dress more informally or casually than depicted in these books.

The two realistic books about kindergarten children, Starting School (Hurwitz 1998) and Rachel Parker. Kindergarten Show-Off (Martin 1992) focus on the behaviour management of the classroom. Each of the twins in Starting School likes his teacher and thinks she is the best teacher. Mrs Greenstein has twenty years of teaching experience, while Ms Boscobel is only in her second year of teaching. The reader sees little of the classroom experience, which usually focuses on the antics of the twins. The reader overhears the two kindergarten teachers in the teachers' room, where they discuss which one of the twins is the most difficult. The extended dialogue in the teacher's room focuses only on the behavior of the twins.

'This morning was awful! It's a good thing I have only one of those Cott twins in my classroom. ' said Mrs Greenstein..

(Ms Boscobel)'Imay be a relativelynew teacher. but I doubt that there will ever be another child like Marcus Cott. I'm sure he is by far the most difficult of the two.'

(Hurwitz 1998, p.16-7)

Mrs Bee, in Rachel Parker, Kindergarten Show-Off (Martin 1992) displays expert classroom management and avoids being the judge in kindergarten squabbles. When Olivia enters the room and calls to Mrs Bee that she has something to share, Mrs Bee asks if Olivia can save it for sharing time and Olivia agrees. Olivia and Rachel are very competitive and keep trying to outdo each other.
Mrs Bee skilfully avoids this competition as she asks Olivia and Rachel to read aloud to the class. After fighting over the teacher's big chair, the girls discover that both of them will fit into the chair. When Olivia does not know a word, she looks to Mrs Bee, her teacher for help. Mrs Bee is sitting on the floor with the children and states that she cannot read yet. Rachel tells Olivia the word and on the next page Olivia helps Rachel with a word. Mrs Bee is a thinking, caring and soft-spoken professional, who models classroom management by quiet example rather than over reacting to the whims of five year olds.

Similar to Mrs Bee, Mr Slinger (Henkes, 1996) also expects class members to wait until recess or sharing time if they want to share something. However, Lilly can't wait and proceeds to share the contents of her purple plastic purse, but she finds out that $\mathrm{Mr}$ Slinger can be a disciplinarian. Although Lilly gets her belongings back with a note from Mr Slinger at the end of the day, she is still not satisfied. With encouragement from her parents, Lilly apologizes to $\mathrm{Mr}$ Slinger and learns to like her teacher once again. Thus, classroom management is seen in some of these books.

With high standards and an era of school reform, kindergarten needs to become a more academic place. First, very little instruction and few academics were visible in any of these kindergarten stories. Starting School made no mention of academics or professional concerns of teaching. The teacher in Rachel Parker, Kindergarten Show-Off has a very small part in the story. The reader does not see Mrs Bee teaching, only managing the class.

Little teaching goes on in $\mathrm{Mr}$ Slinger's classroom. He reads aloud during story time, and he has a light bulb lab where students may go in their free time. However, the reader does not learn any more information about $\mathrm{Mr}$ Slinger's teaching or the methods that he uses. Miss Bindergarten does not share her teaching with the reader. Most of her instruction is inferred through the illustrations, since the text is minimal. Miss Bindergarten models well the task of setting up for teaching, whether she is opening the classroom after the summer holiday or preparing for the $100^{\text {th }}$ day celebration or preparing for the substitute. 
However, the reader does not see Miss Bindergarten teaching. The reader sees no instruction that Miss Cribbage offers to the class. Miss Cribbage mentions the things that occur during the first 100 days of school, such as on day 9 she shows the class a map of the night sky while some children role play the planets and on day 14, Miss Cribbage gives the class gold stars for writing their names without any mistakes. But there is no evidence of instruction for the reader to look at the instructional practices employed.

In this collection of books about kindergarten, there is very little evidence of instruction or academics being present. In the quest to raise standards, academic objectives are entering kindergarten, such as the formal study of letters and phonemic awareness as well as math concepts. However, two new stories exhibit some academic phase. In Letters and Sounds (Wells 2001b) Mrs Jenkins leads the class in singing the alphabet song. The class is asked to join in and sing the letters of the alphabet. In addition the reader is asked to become involved and to name the random letters of the alphabet appearing at the bottom of the page. On the next page Timothy and Yoko learn to write their names while readers are asked to write their name on a piece of paper. Each page ends with an activity for the reader. These activities follow practices that theorists recommend for children entering kindergarten. The second volume, How Many? How Much? (Wells 2001 a) looks at math concepts in a similar manner.

Up until the two recently published books by Wells, there was no explicit academic emphasis in the kindergartens found in the sampled children's literature. In some cases, the kindergarteners in these titles came to school knowing how to read, such as the Cott twins in Starting School, and Rachael and Olivia in Rachel Parker, Kindergarten ShowOff. Their teachers marvelled at the children's reading, but they made no attempt to teach the rest of children in their classes to read. However, with the emphasis on high standards and making the initial year of school entry one with academic goals instead of a year of play, academic goals have crept into children's literature with the assistance of educational consultants.

Child involvement in educational activities is present in these titles, but there is still no attention paid to the teacher's pedagogy. Singing the alphabet song is a way to review the letters of the alphabet, but how did Mrs Jenkins teach the letters of the alphabet to her pupils?

\section{Stories about Teachers in Primary or Elementary Schools}

The real work of school traditionally begins in primary or elementary schools, usually grades $1 \mathrm{t}$ through 5 or 6 . In these sampled stories, the first grade is noticeably absent. In this paper, as well in a previous study (Bushner 1997), school stories about first grade do not appear in quality American literature for children. Reading schemes or materials designed just for the classroom are not part of my assembled texts. This paper reviews only quality American literature for children in search of the image of schools and teachers.

In the primary or elementary grades, children appear undecided at first whether they will like their teacher or not. This question about liking teachers seems to run across the sampled books depicting second or third grade. The teacher has to earn the child's favourable rating and needs to make the classroom a friendly place for them. The children start out the school year with trepidation and wait for teachers to prove themselves.

In a series of titles that Suzy Kline writes, for example (Kline 1993, 1998 and 1999), about second and third graders, a common character that appears across all her school stories is Miss Mackle, the teacher. At one point, Miss Mackle also decides to change grades from second to third grade, just like her students. The children like Miss Mackle and she conducts a traditional child-friendly classroom. She has earned the good will of her students. In Trouble with Teacher (Demuth 1995) Montgomery is a third grader, but he is just not sure whether he likes his teacher, Mrs Wix. She is harder than his second grade teacher. Montgomery worries about flunking the weekly spelling test. When Mrs Wix returns Montgomery's spelling paper, she comments that spelling isn't his best subject and suggests that Montgomery come in early one day to learn how to use the spell checker, since he writes such good stories. Thus, Montgomery begins to view Mrs Wix as nice, since she recognizes his strengths and not just his weaknesses. 
Mr Wilder is the third grade teacher in Third Grade Pet (Cox 1998)who allows the children to take turns taking care of the class pet rat on the weekends. One girl takes the pet when it is not her turn. She tells Mr Wilder the truth. He says that he is disappointed in her but he knows that she will not do it again. To third graders, teachers are being nice when they understand the reasons for children's failures and help them to compensate for these failures. In the sampled books, the second and third graders decide that teachers are nice, only after specific incidents cause the teacher to earn the label. In the sampled books above the third grade, there is no discussion about whether the student thinks the teacher is nice or not, but rather whether the teacher likes the student, as Dexter Plum in Fourth Grade Weirdo (Freeman 1999) is sure that his teacher does not like him. While Jackie in Keep Ms Sugarman in the Fourth Grade has the hardest teacher in the school, yet she is sure that her teacher likes her and this makes school much more enjoyable.

In the primary or elementary grades the physical description of the teacher is still important and this extends across the entire level. Often this description includes more than specific clothes and extends to possessions or qualities. For example, in Keep Ms Sugarman in the Fourth Grade (Levy, 1992) the text describes Ms Sugarman as short and a little dumpy with a lot of gray hair showing. Mrs Granger, the fifth grade language arts teacher in Frindle (Clements 1996) has almost white hair that is swept away from her face to nest on the back of her head; has two jacket and skirt outfits, one blue and one gray; drives a blue car; and has perfect attendance.

As to the pedagogy or instructional practices displayed in the selected books, there are lists of practices. For example, in the titles by Suzy Kline (1993, 1998, and 1999) the reader learns that desks are usually arranged in rows, the children give oral reports, Miss Markle reads stories aloud to the class, puts on plays with her class and takes the class on field trips. The specific instructional decisions that Miss Markle makes are unknown as are the objectives of these activities. Mrs Wix, the teacher In Trouble with Teacher believes in the weekly spelling test and shows Montgomery how to use the spell checker as she tries to offer support for his spelling. Again, the reader does not know much about the pedagogy employed by Mrs Wix. In Third Grade Pet, the focus of the book is the class pet. There is very little pedagogy or teaching practices displayed in the sampled titles depicting grades two and three.

Although stories are set in the classroom, such as Keep Ms Sugarman in the Fourth Grade (Levy 1992) and Frindle (Clements 1996), there is little attention given to teaching the entire class but instruction seems to focus on one student who either attracts the teacher's attention positively or negatively. Ms Sugarman encourages Jackie to write poetry and helps her to develop a more positive attitude toward school. In Frindle fifth grader Nicholas and Mrs Granger do not get along from the start of the school year. Mrs Granger is a very set teacher who knows what she wants to teach and tries to impart to students a love of the dictionary. Nicholas is intent on wasting time and annoying Mrs Granger. Outside of school, Nicholas coins a new word and enlists a group of classmates to take an oath to never use the word 'pen' again, but instead to use the word FRINDLE. In Mrs Granger's class Nicholas disrupts the class with the use of the word FRINDLE and Mrs Granger lets Nicholas know that she will not allow her class to be disrupted again in the future. The situation between Mrs Granger and Nicholas soon escalates throughout the school. Eventually, the principal becomes involved along with the local town newspaper. When the newspaper interviews Mrs Granger, she says:

It is not a battle. I am merely helping my students to see that this foolishness should stop. Such a waste of time and thought. There is no reason to invent a new and useless word. They should each learn to use the words we already have. But of course, all of this is just a silly fad, and when you add an e to fad, you get fade. And I predict this fad will fade.

(Clements 1996, pp.61-62.)

After the media publicizes the story, Mrs Granger appears to have given up on the word. Mrs Granger is an exacting teacher who holds her students to high standards and wants to make the most of instructional time. During most of the book, the author portrays her as a rigid teacher with little interest in her students. The displayed pedagogy 
is very traditional but it is evident that Mrs Granger has a strong knowledge of English, the subject that she teaches. The author conceals the interest that Mrs Granger takes in her students until ten years later when Nicholas is in college. She is a caring teacher who displays a genuine interest in her students along with striving for high standards.

Two titles in the elementary grouping are an inversion of the usual teacher story. The children realize that their teacher is not teaching them anything and they seek to change teacher behavior in one instance and decide to become good readers in another case, so their teacher will not be dismissed. In The Landry News (Clements 1999) and The $6^{\text {th }}$ Grade Nickname Game (Korman 1998) there is little evidence of current pedagogy displayed. Once students in The Landry News motivate their teacher to teach, he shares with the reader through reflection his open philosophy of teaching.

In The Landry News, Clements (1999) takes a harsh look at a teacher in a fifth grade classroom. Mr Larson believes that children learn best when they learn things on their own. Cara Landry, a student, becomes annoyed with no teaching in the classroom and she decides to publish a newspaper with an editorial that exposes the lack of teaching in the classroom.

This experience causes Mr Larson to reflect on the kind of teacher that he is and to recall some teachers from his own schooling. On the Monday next, he returns to school and teaches a lesson. Soon the newspaper expands into a meaningful class project. However, the principal has been looking for a reason to fire Mr Larson, so when a story is published in the newspaper that the principal views as inappropriate, the school board asks Mr Larson to appear concerning a disciplinary hearing. With the children's help, Mr Larson is vindicated. Mr Larsen is a rigid teacher who seems unwilling to compromise, but surprisingly, he reflects on his past accomplishments in teaching, listens to his students, and modifies his practices to become the teacher he once was.

Almost everyone in the Old Orchard Public Schools receives a nickname from two sixth graders in class $6 \mathrm{~B}$ in The $6^{\text {th }}$ Grade Nickname Game (Korman 1998). Class 6B has a substitute teacher for the year, Mr Hughes, the high school assistant football coach. Mr Hughes teaches as if he were coaching a sports team and does not display usual classroom pedagogy. Some students in room $6 \mathrm{~B}$ overhear talk about the superintendent's dissatisfaction with the low scores on the practice reading test from room $6 \mathrm{~B}$. The students like $\mathrm{Mr}$ Hughes and do not want to see him leave. Therefore, they discuss among themselves how to study to score well in the State Reading Assessment. Room 6B spends all their time reading books and they score in the top one percent on the State Reading Assessment. Again, in the upper elementary grades, the students save the teacher's job.

In reflecting on the image of teachers in the elementary grade stories, the children in the lower grades look more favourably on their teachers. Once students reach the fifth or sixth grade, the students seem to try to shape the teachers, if they do not meet their expectations. In these two examples, the teachers are unaware of how to improve their practice. One teacher improves through a painful student initiative. As a model for children, this type of novel presents a distorted view of teaching and limits the knowledge that teachers should have

In the books set in primary or elementary schools, there is little evidence of high standards needed for educational reform. Outside of Mrs Granger and Ms Sugarman, who seem to have a strong knowledge of the subjects they teach, most of the teachers do not display any depth of content knowledge. Mr Larsen knows more about teaching than it appears initially, but he is an example of a teacher who has burned out. Hopefully, the experience with these students will make a difference and motivate him to be the teacher he once was. Mr Hughes is the stereotypical football coach who does not know how to teach.

\section{Stories about Teachers in Middle Schools}

Middle School is that time between elementary school and high school, often pre-teen and young teen years. The grade span found in middle schools in the United States varies by community. A well known middle school piece of children's literature is The View from Saturday (Konigsburg 1996) which won the prestigious 1997 Newbery Award. This award is given in the United States 
for the best-written story for children. In the story, Mrs Eva Marie Olinski, a paraplegic, has just returned to teaching at Epiphany Middle School after her automobile accident. Mrs Olinski coaches the school's academic bowl team and selects four sixth graders to represent the school. Much of the book focuses on Mrs Olinski trying to explain how she makes her decisions for the academic team, but in actuality, she is not aware of how she reaches her decisions. The novel presents teacher decision-making in a less than stellar manner. Since the novel concerns an extra curricular activity, there is little information on the actual instruction in the classrooms shared. Since the Epiphany Middle School wins the academic bowl, the team had to exhibit high standards. However, how this carries over into the classroom is not known because the reader does not have an opportunity to view the classroom.

Another middle school award winning book is The Skin I' $m$ In (Flake 1998) that won a Coretta Scott King Award for new authors. The story takes place in McClenton Middle School. Malecka Madison, a seventh grade student narrates the story and presents the book from her point of view. There is a new English teacher, Miss Saunders. Typical of school stories, there is a physical description of the new English teacher Miss Saunders who is tall and fat, has the smallest feet, has a giant white stain spread halfway across her face, looking as though somebody tossed acid at her; and she dresses to the nines. This is Miss Saunders' first year of teaching. Her advertising company and the school board develop a program that allows professionals to take a leave of absence for a year to teach in inner-city schools.

Throughout the story the students give Miss Saunders a difficult time as she struggles with classroom management, making school interesting, holding students to high standards, teaching quality literature, while parents telephone the school to complain about the amount of homework. Since the story is narrated by a seventh grader, the reader sees Miss Saunders through the eyes of a twelve year old and her concerns with discipline and student-to-student gossip as opposed to a focus on teaching pedagogy. In a rare teacher-to-teacher dialogue, that the seventh grade narrator overhears, Miss Saunders and a veteran teacher, who both attended the same college, discuss some issues that Miss Saunders is having with her students as she complains about the test-taking skills of the students. The veteran teacher says:

That's not unusual for many of our kids. But you have managed to get them to like Shakespeare, and to read something other than the TV Guide. Help them learn to test better. Don't kill their spirits by flunking them and making them think that nothing they've done really counts...

(Flake, 1998, p.113).

The book realistically presents a fictional look at a new teacher, who has left an unrelated career for teaching. New teachers left on their own without professional support often experience difficulty, but Miss Saunders has an informal mentoring relationship with a former college classmate. However, school systems need to formalize the mentor relations. Middle school students are the audience of this book and they see the classroom through the eyes of a peer and not the teacher or what the teacher needs to be effective.

\section{Stories about Teachers in Rural Schools}

In sparsely populated parts of the United States, schools may have multiple grades in one or two rooMs These small rural schools typically span the elementary grades until high school. After these schools, students travel, often long distances, to high school. The Seal Island School (Bartlett 1999) is a two-room school located on an island off the coast of Maine. Other than children presenting oral reports or bringing pets to school for show and tell, the reader views little instruction or pedagogy provided by Miss Sparling. The novel defines Miss Sparling by her appearance and the fact that a student thinks she is the best teacher in Maine.

A book that depicts a rural and isolated Athabascan community is The Year of Miss Agnes (Hill 2000). Although published for the first time in 2000, this story is set in Alaska over fifty years ago, when Alaska was only a territory and not yet a state. As the story opens, Frederika, the nine-year old girl who narrates the story, watches a plane take a nameless teacher away from the village. The children had anticipated that the teacher would not last the year out. Again, children offer an incidental evaluation of a teacher. In town, Fred hears 
gossip that her new teacher, Agnes Sutterfield, is an experienced teacher and the kids will not get away with anything.

As an introduction, the author presents a physical description of Miss Agnes, who is British, 'talks funny', and wears pants. She arrives at school with a record player, a whole bunch of books, and pictures to hang on the wall. She likes student desks in a circle and places her desk in the corner of the room. She disposes of the old textbooks. When children expect to be hollered at, she will just look at them with her eyebrow up and her mouth pushed to one side. To brighten the classroom, Miss Agnes assigns everyone the task of making a picture after she shows the class how to rule a margin for the picture. If the children write their letters carelessly, Miss Agnes gives them back their work and makes them do it over again. Fred feels that Miss Agnes is going to make certain the students really learn things. Miss Agnes reads aloud expressively to the children from Robin Hood, uses the map to teach geography, and teaches math so no one will be cheated.

One day when Fred's sister Bokko brings lunch to Fred, Miss Agnes asks why Bokko is not in school. Even though Bokko is deaf, Miss Agnes insists that she attend school and speaks with Bokko's mother to convince her. Miss Agnes works individually with Bokko and even sends for special books, so Bokko may leam sign language. In the evening. Miss Agnes tutors adults. Instead of using the traditional readers with Spot and the rest of the family, Miss Agnes writes her own books and introduces vocabulary that is more appropriate, and experiences suited to the children's reading. The children find it easier to learn to read this way. In addition, she has students writing stories because one learns to read by writing as well as by reading. Miss Agnes also tries to help the children learn to speak appropriate English according to their audience, whether it is people in the village or the city or away at school. In this novel, there is more information about what occurs in the classroom than in most other books. Miss Agnes carefully considers her pedagogy and instructional practices.

Although The Year of Miss Agnes is set over 50 years ago, it depicts a very positive view of teachers and school.
Miss Agnes displays an intense desire for children to learn, or she will find another way to teach something. She makes school interesting for children, she exhibits sound instructional practices, she obtains information when she does not know something, and she practises inclusion of a handicapped child in her classroom. Miss Agnes is a wonderful role model of a teacher for children. As a teacher, children see Miss Agnes planning, conferring with parents, possessing subject knowledge and pedagogical skills, and meeting the needs of diverse learners. She truly passes on to her students the gift of society's cultural, intellectual, and aesthetic achievements. Although the story is set over fifty years ago, Miss Agnes is a very realistic teacher and displays qualities valued in contemporary teachers.

\section{Conclusion}

Teaching is often viewed as a female occupation. Stereotypically, there is the image of the old spinster teacher. Interestingly, two of the most rigid teachers depicted in the selected body of fiction are Mrs Wix (Demuth 1995) and Mrs Granger (Clements 1996). The old spinster image does not apply to these married teachers. In the United States, the teaching force is becoming more diversified. This includes men in the teaching force as well as an effort to recruit more teachers from minority cultural groups, both male and female. In the representative literature for children and pre-adolescents in this paper, some of the books have male teachers. In an unduplicated count of teachers, 6 out of 16 teachers depicted in the corpus of titles are male. However, only one female teacher is from a cultural minority. Thus, these books come close to realistically mirroring the teaching force in the United States. Schools systems have large proportions of male teachers but many systems are still trying to attract more teachers from minority cultures. Often school systems offer mid career change programs to attract potential teachers, such as occurred in The Skin I' $m$ In.

In the actual world of teaching, Shulman (1999) reiterates the importance of the teacher to the learning process. Yet, the authors of these works of fiction do not portray this. The teacher is present in the titles, but usually a child stands out as a dominant character. This literature is written for children primarily and children are mainly 
interested in what they and age mates do, not what adults do. Of the selected titles, Miss Agnes in The Year of Miss Agnes appears to focus on the importance of the learning process. Miss Agnes is child centred, but she translates this into classroom procedures whether she is trying to find out how to teach a deaf child or how to write a reading text that will be the needed level to build on the culture of the children. In The Landry News and The $6^{\text {ih }}$ Grade Name Game, students take responsibility for their own instruction and ensure that their teachers keep their jobs.

In the titles with teachers who teach kindergarten, there is no emphasis on the learning process. Kindergarten is a pleasant place and children and teachers need to be happy, but there is no visible attention to focusing on the learning process. Even in Letters and Sounds (Wells 2001a) or How Much? How Many? (Wells 2001b), Mrs Jenkins models or leads activities rather than actually teaching concepts.

Teachers also need to display a strong knowledge of the subjects they teach. The authors show little evidence of teacher knowledge in the fictional texts. The reader of these texts really has to look hard in the text to find the knowledge of the teacher characters. Miss Saunders in The Skin I' $m$ In seems knowledgeable about English, including Shakespeare and holds her students to high standards. However, the students complain that her class is too hard. Mrs Granger is knowledgeable about English or Language Arts, although the author portrays her very rigidly and the battle over the word FRINDLE seems to mask her knowledge of English. Miss Agnes is a generalist. She knows where to find whatever information she does not know. Although being a generalist may have worked in the day of the one room classroom, the focus in education today is on depth of content or subject matter knowledge. The majority of the teachers depicted did not display strong content knowledge, but were more concerned with classroom management, extra curricular activities, class pets, and ensuring that children enjoy school.

After reflecting on the corpus of works, I would agree with Moore (1995) that most books present a distorted view of the work of teachers to children. If a reader wants to know what it is like to be a teacher, the reader would learn little useful information from these novels or picture books. As for pre-service teachers, most of the books fail to present a current look at teaching and/or evidence of the pedagogy employed. Since I looked at books that were published in the 1990 s or later, I would conclude that the publication date is no guarantee that the book will present a positive view of school. The Year of Miss Agnes offers the most positive view of school and this book is set over fifty years ago. It appears to me, that the authors of children's books do not view education as an active, changing field but rather a staid enterprise unchanged since they went to school.

Children are the intended audience for these school stories. Hence, the children in the stories are the centre of attention. The teacher is just there. Frindle by Andrew Clements is an unusual school story that is rated well by literature critics and is well liked by children. For example, The Horn Book Guide, a biannual publication that rates all hardbound books published in the United States, rates Frindle as a "l", the outstanding category. Many states in the United States have children's choice reading programs and children in more than 19 states have rated Frindle as their favorite book. Thus, there must be something about the head-to-head clash between a student and his teacher that makes the book so popular. Academics can look for specific characteristics in books, but the real issue is whether children choose to read the book. As a teacher educator, I'll have to focus on finding the best examples of pedagogy and practice in good classrooms and send my pre-service students to observe those classrooms.

\section{REFERENCES}

Burnaford, G. E. (1994). 'Personal memories and social response: Teacher images in literature for older children', in P. B. Joseph and G. E. Burnaford (eds) Images of Schoolteachers in Twentieth-Century America. New York, St. Martin's Press.

Bushner, D. E. (1997). 'A look at how children's authors depict books or reading in literature for children published from 1990 through 1995', The Primer: The Journal of the Massachusetts Reading Association 26, 2: 4-19.

Clark, B. L. (1996) Regendering the School Story. New York, Garland Publishing Inc. 
Commonwealth of Massachusetts (2000) English Language Arts Curriculum Frameworks. Malden, MA, Department of Education.

Durrington, M. (1994) 'Novel teachers: The image of teachers in Australian children's literature', Magpies 9, 4: 5-8.

Moore, S. A. (1995) 'Teachers, teaching, and classrooms in children's literature: How authors and illustrators portray schooling', Research Report presented at the International Reading Association Conference, Anaheim, CA, May.

Shulman, L.S. (1999) 'Forward', in L. DarlingHammond and G. Syles (eds) Teaching as the Learning Profession: Handbook of Policy and Practice. San Francisco, CA, Jossey-Bass, pp.xi-xiv.

Tell, C. (2001) 'Appreciating good teaching: A conversation with Lee Shulman', Educational Leadership 58, 5: 6-11.

Trousdale, A. M. (1994) 'Teacher as gatekeeper: Schoolteachers in picture books for young children', in P. B. Joseph and G. E. Burnaford (eds) Images of Schoolteachers in Twentieth-Century America. New York, St. Martin's Press.

White, M. (2000) 'Important challenges ahead in curriculum', Education Times, Victoria, Department of Education, Employment and Training, p. 10.

Literature for Children and Pre-Adolescents

Bartlett, Susan (1999) Seal Island School. Illustrated by Tricia Tusa. New York, Viking.

Clements, Andrew (1996) Frindle. Illustrated by Brian Selznick. New York, Simon and Schuster.

Clements, Andrew (1999) The Landry News. Illustrated by Salcatore Murdocca. New York, Simon and Schuster.
Cox, Judy (1998) Third Grade Pet. Illustrated by Cynthia Fisher. New York, Holiday House.

Demuth, Patricia Brennan (1995) In Trouble with Teacher. Illustrated by True Kelley. New York, Dutton.

Flake, Sharon G. (1998) The Skin I'm In. New York, Hyperion, Jump at the Sun Books.

Freeman, Martha (1999) Fourth Grade Weirdo. New York, Holiday House.

Henkes, Kevin (1996) Lilly's Purple Plastic Purse. New York, Greenwillow.

Hill, Kirkpatrick (2000) The Year of Miss Agnes. New York, McElderry Books.

Hughes, Thomas (1999) [1856] Tom Brown's Schooldays. New York, Oxford Press. Introduction by Andrew Sanders.

Hurwitz, Johanna (1998) Starting School. Illustrated by Karen Dugan. New York, William Morrow Co.

Konigsburg, E. L. (1996) The View from Saturday. New York, Atheneum.

Kline, Suzy (1993) Song Lee in Room $2 B$. Illustrated by Frank Remkiewicz. New York, Viking.

Kline, Suzy. (1998). Horrible Harry Moves Up to Third Grade. Illustrated by Frank Remkiewicz. New York, Viking.

Kline, Suzy (1999) Song Lee and the 'I Hate You' Notes. Illustrated by Frank Remkiewicz. New York, Viking.

Korman, Gordon (1998) The $6^{\text {th }}$ Grade Nickname Game. New York, Hyperion.

Levy, Elizabeth (1992) Keep Ms Sugarman in the Fourth Grade. New York, HarperCollins.

Martin, Ann (1992) Rachel Parker, Kindergarten Show-Off. Illustrated by Nancy Poydar. New York, Holiday House. 
Slate, Joseph (1996) Miss Bindergarten Gets Ready for Kindergarten. Illustrated by Ashley Wolff. New York, Dutton.

Slate, Joseph (1998) Miss Bindergarten Celebrates the $107^{\text {th }}$ Day of Kindergarten. Illustrated by Ashley Wolff. New York, Dutton.

Slate, Joseph (2000) Miss Bindergarten Stays Home from Kindergarten. Illustrated by Ashley Wolff. New York, Dutton.

Wells, Rosemary (2000a) Emily's First 100 Days of School. New York, Hyperion Books for Children.

Wells, Rosemary (2000b) [1981] Timothy Goes to School. New York, Viking. (2000 edition has new illustrations.)

Wells, Rosemary (200 la) How Many? How Much? New York, Viking.

Wells, Rosemary (2001b) Letters and Sounds. New York, Viking.

\section{BIOGRAPHICAL NOTE}

Diane E. Bushner is an associate professor at Salem State College in Salem, Massachusetts (USA). She teaches reading courses, children's literature courses, and coordinates the graduate reading program. She co-reviews books for the 'Book Beat' column in The New England Reading Journal. The past three years she has served on the selection committee for The Notable Books for a Global Society. She currently serves as a member of the National Council Teachers of English Notable Children's Books in the Language Arts Committee.

Diane intends to continue to research her interest in the depiction of reading and writing in children's literature.

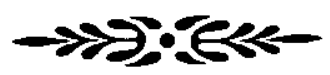

